\title{
DROPLETS FROM THE PLANKTON NET -XVII. A Small Collection of Chaetognaths and Pelagic Tunicates from the North Eastern Part of the Indian Ocean-
}

\author{
AUTHOR(S): \\ Tokioka, Takasi
}

\section{CITATION:}

Tokioka, Takasi. DROPLETS FROM THE PLANKTON NET -XVII. A Small Collection of Chaetognaths and Pelagic Tunicates from the North Eastern Part of the Indian Ocean-. PUBLICATIONS OF THE SETO MARINE BIOLOGICAL LABORATORY 1955, 5(1): 75-80

\section{ISSUE DATE:}

1955-12-20

URL:

http://hdl.handle.net/2433/174534

RIGHT: 


\title{
DROPLETS FROM THE PLANKTON NET ${ }^{13}$
}

\author{
TAKASI TOKIOKA
}

Seto Marine Biological Laboratory, Sirahama

With 5 Text-figures and 3 Tables

\section{A Small Collection of Chaetognaths and Pelagic Tunicates from the North Eastern Part of the Indian Ocean.}

(Figs. 19-21)

The present material consists of three samples respectively collected in the following localities during the exploring voyage of the Syunkotu-maru, a surveying ship of the Simonoseki College of Fisheries.

1. Near the Nicobar Islands $(0-100 \mathrm{~m})$, Dec. $27-28,1953,(11-15 \mathrm{~h})$; obtained by two hauls.

2. Near Nias Island $(0-100 \mathrm{~m})$, Jan. 2-5, 1954 ; obtained by three hauls.

3. Between Bali and Lombok (0-100 m), Jan. 18-22, 1954 (13-16 h); obtained by three hauls.

This contains the following 27 forms in the proportions shown below.

Table I. Cheatognaths. (Numerals in parentheses indicate the percentages.)

\begin{tabular}{l|r|r|r}
\hline \multicolumn{1}{|c|}{ Locality } & Nicobar & Nias & Bali-Lombok \\
\hline Species & $2(3)$ & $4(3)$ & $3(2)$ \\
Sagitta hexaptera & $20(30)$ & $34(21)$ & $55(35)$ \\
Sagitta enflata & $1(2)$ & & $4(3)$ \\
Sagitta bipunctata & $3(4)$ & $5(3)$ & $15(9)$ \\
Sagitta bedoti & & & $1(1)$ \\
Sagitta pulchra & $5(8)$ & $3(2)$ & $5(3)$ \\
Sagitta robusta & $6(9)$ & $38(24)$ & $32(20)$ \\
Sagitta serratodentata pacifica & $3(5)$ & $7(4)$ & $3(2)$ \\
Sagitta neglecta & $8(12)$ & $34(21)$ & $10(6)$ \\
Sagitta regularis & $18(27)$ & $1(1)$ & $27(\mathbf{1 7})$ \\
Sagitta minima & & $34(21)$ & $1(1)$ \\
Pterosagitta draco & & & $2(1)$ \\
Krohnitta subtilis & 66 & 160 & 158 \\
Krohnitta pacifica & & & \\
\hline
\end{tabular}

1) Contributions from the Seto Marine Biological Laboratory, No. 270.

Publ. Seto Mar. Biol. Lab., V (1), 1955. (Article 4) 

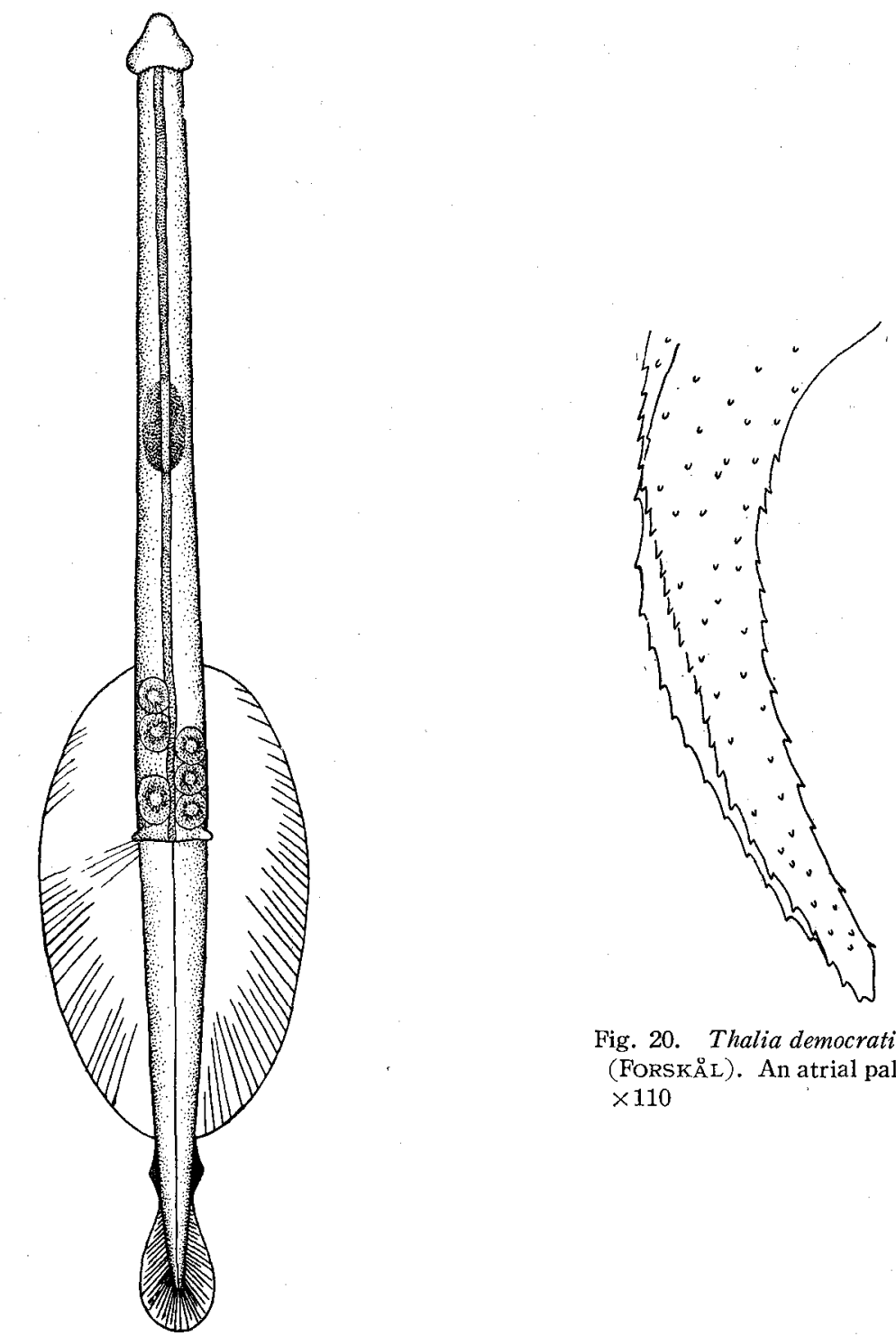

Fig. 20. Thalia democratica (FORSKÄL). An atrial palp. $\times 110$

Fig. 19. Krohnitta subtilis (Grassi). An individual with large mature ova. $\times 15$

Chaetognaths: Sag. enflata, Pterosag. draco and Sag. serratodentata pacifica are the commonest species and next Sag. regularis being followed by Sag. bedoti and Sag. robusta. The single specimen of Krohnitta subtilis from Bali-Lombok (Fig. 19) seems to be noteworthy in having three large mature ova in each trunk-coelom; these ova are enclosed in the range between the anterior end of the lateral fin and tail septum. This individual is $9.6 \mathrm{~mm}$ in length, its seminal vesicles have already bursted. 
Table II. Pelagic tunicates.

\begin{tabular}{|c|c|c|c|}
\hline $\begin{array}{ll} & \text { Locality } \\
\text { Species } & \\
\end{array}$ & Nicobar & Nias & Bali-Lombok \\
\hline Thalia democratica & $\mathrm{r}$ & 1. & $\mathrm{r} r$ \\
\hline Doliolum Amme & & 1 & \\
\hline Oikopleura longicauda & & 4 & \\
\hline Oikopleura fusiformis & 1 & 6 & 3 \\
\hline Oikopleura gracilis? & & 2 & \\
\hline Oikopleura rufescens & & & 1 \\
\hline Oikopleura cophocerca & 2 & 2 & 1 \\
\hline Stegosoma magnum & & 5 & \\
\hline Megalocercus huxleyi & & & 1 \\
\hline Fritillaria haplostoma & & & 1 \\
\hline Fritillaria formica & 1 & & \\
\hline Fritillaria pellucida & & & 1 \\
\hline Fritillartia borealis f. sargassi & & 1 & 1 \\
\hline Fritillaria venusta & & & 1 \\
\hline
\end{tabular}

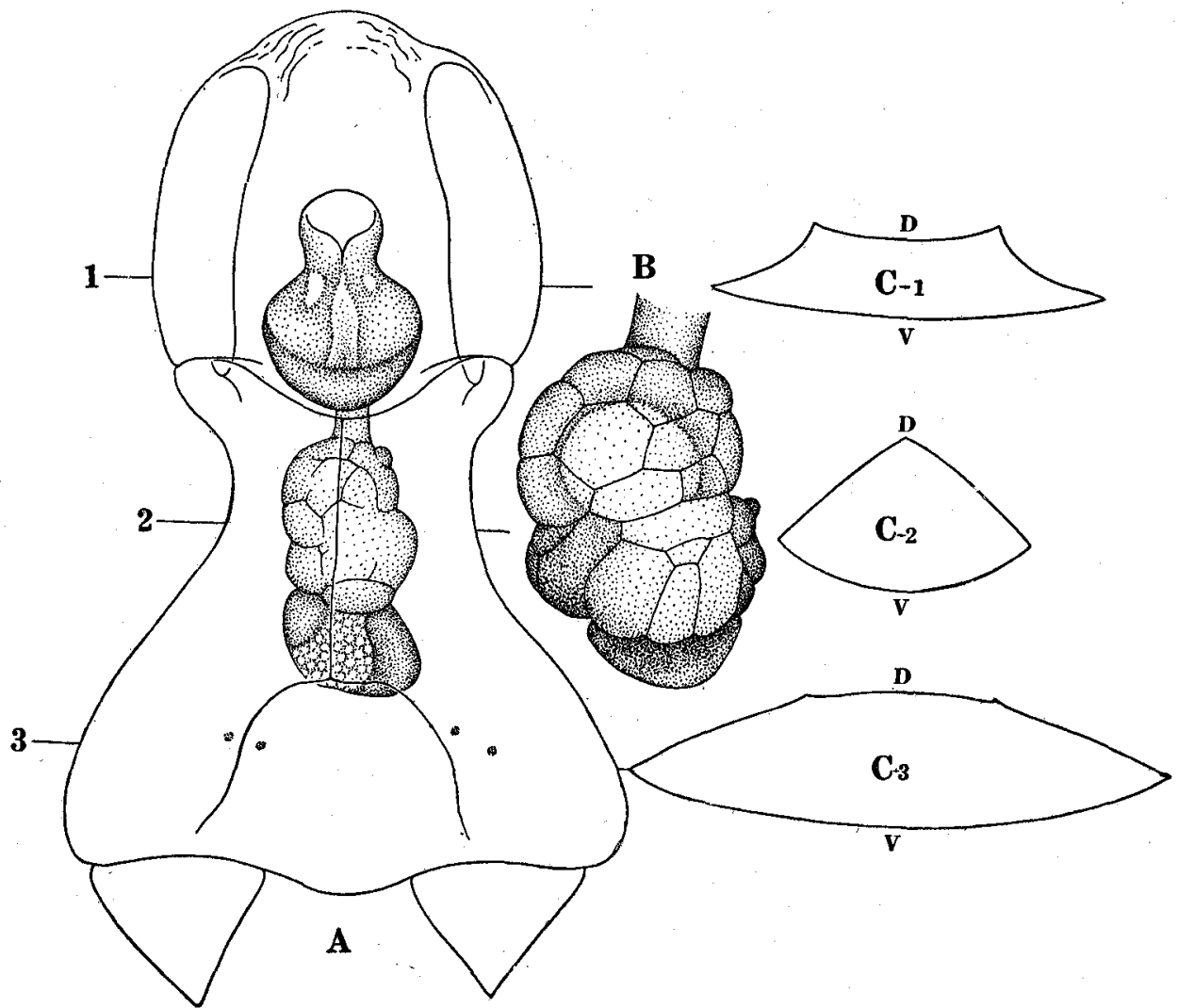

Fig. 21. Fritillaria venusta LoHMANN.

A-Dorsal side, $\times 110 ; \mathrm{B}-$-Alimentary organ, dorsal, $\times 200 ; \mathrm{C}_{1-3}$-Three sections of the test, respectively on the levels $1\left(\mathrm{C}_{1}\right), 2\left(\mathrm{C}_{2}\right)$ and $3\left(\mathrm{C}_{3}\right), \times 110$. d-dorsal, v-ventral. 
Salpas: All the solitary forms of Thalia democratica found in the material are provided with the atrial palp simply pointed distally and with roughly triangular section; the palps are usually furnished with minute prominences (Fig. 20).

Appendicularians: Although the single specimen of Fritillaria venusta from Bali-Lombok is small, about $900 \mu$ in length of the trunk, and quite immature, it is preserved so perfectly that the shape of its soft test of the trunk may be easily understood; three sections of the test are shown in Fig. 21.

Lastly I express my hearty thanks to Prof. T. CHIBA and Mr. S. Tsuruta by whose courtesy the present material was submitted to my examination.

\section{Short Notes on a Few Appendicularians Collected in the "Kurosio" off Siono-misaki.}

(Figs. 22 and 23)

A few appendicularian specimens were selected out of the plankton samples collected by the surveying ship of the Kôbe Marine Observatory in the "Kurosio" off Siono-misaki in May 1954 and submitted by courtesy of Mr. K. Furuhashi of the Observatory to my close examination. This material comprises:-

$\begin{array}{ll}\text { Oikopleura albicans (LEUCKART) } & 10 \text { individuals } \\ \text { Oikopleura cophocera GEGENBAUR } & 2 \\ \text { Stegosoma magnum (LANGERHANS) } & 2 \text { ", } \\ \text { Althoffia tumida LOHMANN, } 1892 & 1 \text { tail } \\ \text { Fritillaria fraudax LOHMANN } & 1 \text { individual }\end{array}$

Results of various measurements on these specimens are shown in the last part of this note.

Oikopleura albicans: Subchordal cells increase with growth; for instance, they are merely 28 in a $2910 \mu$ long tail, while they may be as numerous as 77 in a $5350 \mu$ long tail. The arrangement of cells seems to be rather irregular in smaller specimens and becomes regular with growth, being composed of two parallel rows. In the posterior part, however, the arrangement keeps a single row even in fully grown individuals (Fig. $22 \mathrm{D}-\mathrm{H}$ ).

Oikopleura cophocerca: Subchordal cells are divided into anterior and posterior groups, the former comprises 4 cells and the latter consists of 3 ones (Fig. $22 \mathrm{~J}$ ).

Stegosoma magnum: In the larger specimen, the gonad is bent sharply at the posterior end and distinctly interrupted at this point (Fig. $23 \mathrm{~K}$ ).

Althoffia tumida: As the arrangement of numerous (59 on both sides) tail cells differs from that in Pelagopleura, the present tail specimen is considered to belong to Althoffia. The posterior end of the chorda falls considerably in front of the distal end of the musculature (Fig. $22 \mathrm{I}$ ). 


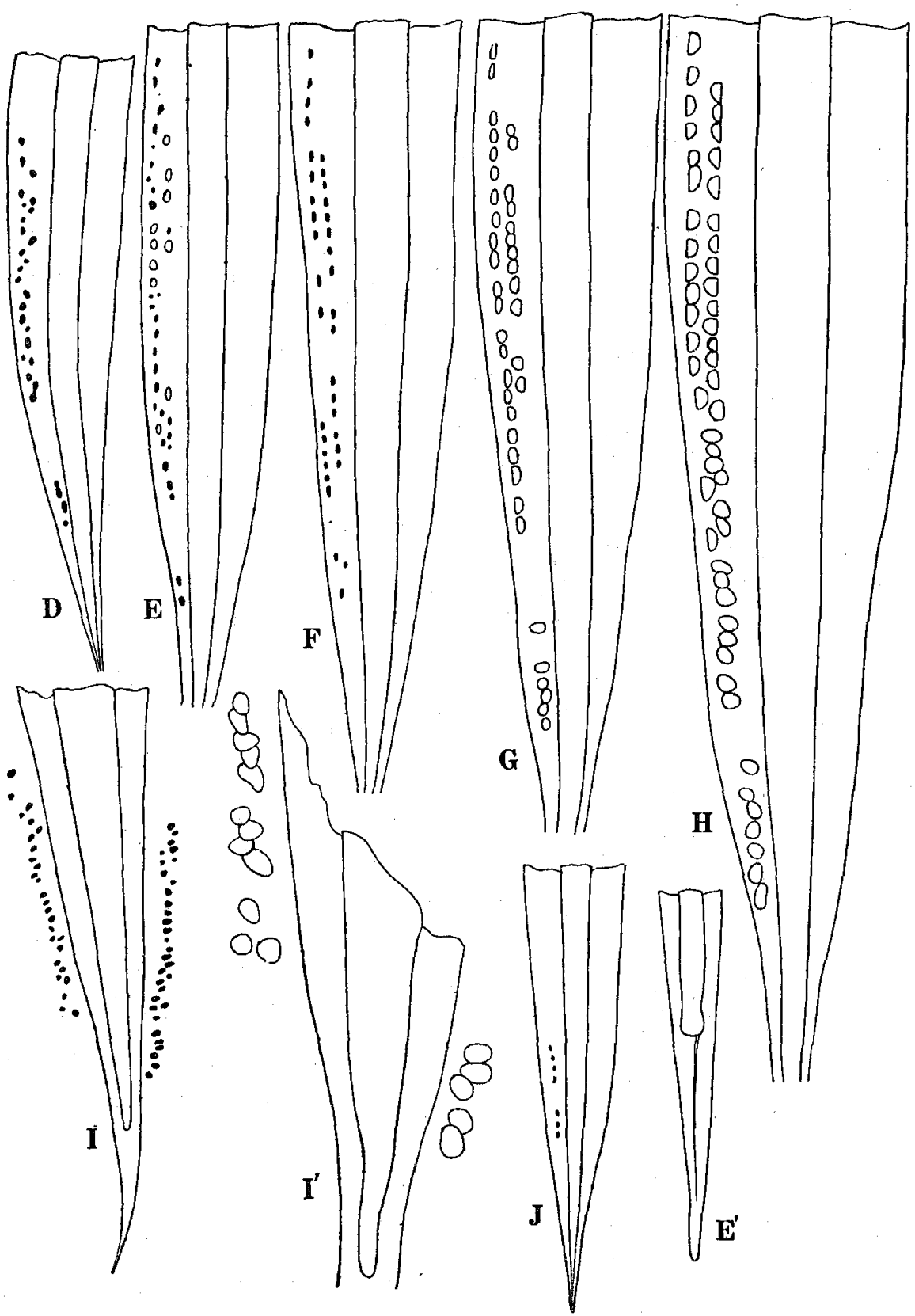

Fig. 22. D-H Oikopleura albicans (LEUCKART). Arrangement of subchordal cells, $\times 47$. $\mathrm{D}-$ Tail length $2910 \mu ; \mathrm{E}-3390 \mu ; \mathrm{E}^{\prime}-$ Distal end of the tail musculature, $\times 200 ; \mathrm{F}-$ $4650 \mu ; \mathrm{G}-4480 \mu ; \mathrm{H}-5830 \mu$. I-Althoffia tumida LoHMann. Distal part of the tail, showing the arrangement of tail cells, $\times 73 ; \mathrm{I}^{\prime}-$ The same, $\times 200$. J-Oikopleura copho. cerca Gegenbaur. Arrangement of subchordal cells, $\times 47$. 
Fritillaria fraudax: The posterior end of the chorda does not reach the distal end of the musculature (Fig. $23 \mathrm{~L}$ ).
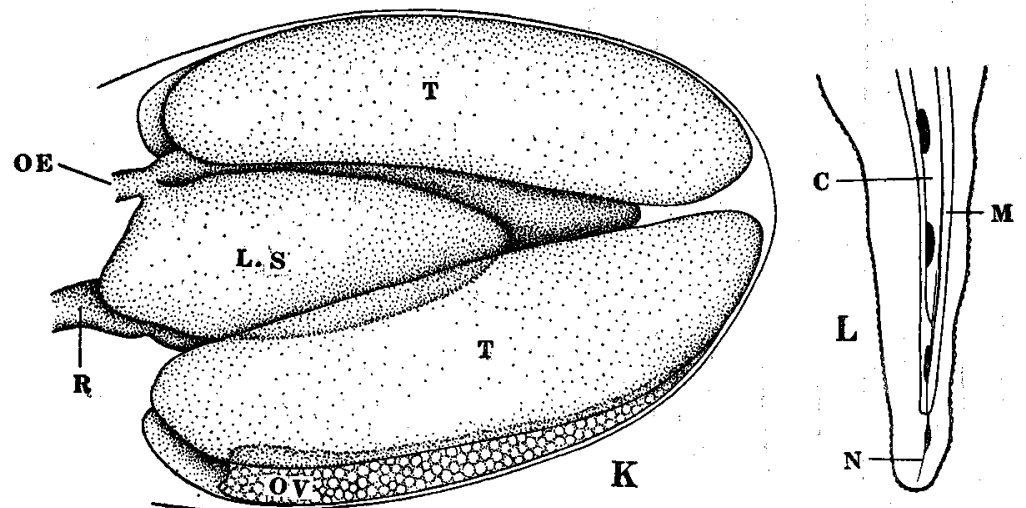

Fig. 23. K-Stegosoma magnum (LANGERHANS). Genital region of the trunk, left side, $\times 47 ; \mathrm{L}-$ Fritillaria fraudax Lohmann. Distal end of the tail, $\times 73$. C-chorda, L.S - left stomach lobe, M-tail musculature, N-nerve, $\mathrm{OE}$ oesophagus, OV-ovary, $\mathrm{R}$-rectum, T-testis.

Table III. Various measurements on the material.

(C...Width of chorda, M.WWidth of tail musculature)

\begin{tabular}{|c|c|c|c|c|c|}
\hline \multicolumn{6}{|c|}{ Oikopleura albicans } \\
\hline $\begin{array}{l}\text { Trunk length } \\
\text { (B) }\end{array}$ & $\begin{array}{c}\text { Tail length } \\
(\mathrm{T})\end{array}$ & $\frac{T}{\mathrm{~B}}$ & $\begin{array}{c}\text { Subchordal } \\
\text { cells }\end{array}$ & $\frac{\mathrm{M}}{\mathrm{T}} \times 100$ & $\frac{\mathrm{C}}{\mathrm{M}} \times 100$ \\
\hline $740 \mu$ & $2910 \mu$ & 3.9 & 28 & 11.3 & 34.8 \\
\hline 930 & 3390 & 3.6 & 39 & 11.8 & 26.8 \\
\hline 960 & 4650 & 4.9 & 36 & 10.1 & 37.9 \\
\hline 1110 & 4480 & 4.0 & 40 & 11.2 & 25.7 \\
\hline 1220 & 5570 & 4.6 & & 10.8 & 29.8 \\
\hline 1390 & 5830 & 4.2 & 52 & 11.8 & 26.0 \\
\hline 1430 & 5350 & 3.7 & 77 & 11.7 & 28.4 \\
\hline 1650 & 6260 & 3.8 & 61 & 11.9 & 28.8 \\
\hline 1870 & 6650 & 3.6 & 59 & 10.5 & 35.7 \\
\hline 1870 & 7300 & 3.9 & 55 & 12.0 & 30.9 \\
\hline \multicolumn{6}{|c|}{ Oikopleura cophocerca } \\
\hline \multirow[t]{2}{*}{540} & 2780 & 5.1 & 7 & 10.8 & 23.8 \\
\hline & 2650 & & 7 & & \\
\hline \multicolumn{6}{|c|}{ Stegosoma magnum } \\
\hline 1610 & 6520 & 4.1 & 8 & & \\
\hline 2000 & 8000 & 4.0 & 8 & & \\
\hline \multicolumn{6}{|c|}{ Althoffia tumida } \\
\hline & 4220 & & $\begin{array}{c}27-32 \\
\text { (Tail cells) }\end{array}$ & 18.1 & 25.0 \\
\hline \multicolumn{6}{|c|}{ Fritillaria fraudax } \\
\hline 1090 & 2550 & 2.3 & & 7.4 & 32.1 \\
\hline
\end{tabular}

